\title{
Germany's brake on European capital-market development
}

\author{
John Grahl \\ Middlesex University Business School, London, UK \\ Photis Lysandrou \\ City University of London, UK
}

\begin{abstract}
In February 2015, the European Commission published a Green Paper in which it put forward the goal to 'build a true single market for capital' for all European Union member states by 2019. The present paper argues that there is no realistic prospect of achieving this goal given that the Green Paper omits any reference to a formidable impediment blocking a European capital-market union: the German government's stance on debt. The inescapable fact is that this government's reluctance to increase the supply of its bonds is depriving the European capital market of one of the essential ingredients necessary to its enlargement on the one hand and to the efficiency of its operation on the other: the former because capital-market enlargement crucially depends on attracting institutional investors who must hold a substantial proportion of their bond portfolios in the form of safe government bonds; the latter because the efficient functioning of the capital markets crucially depends on the efficiency of the money markets where safe government bonds are by far the most important form of collateral.
\end{abstract}

Keywords: Germany, debt brake, European capital-markets union

JEL codes: $G 15, F 36$

\section{INTRODUCTION}

In February 2015, the European Commission (EC) published a Green Paper in which it put forward the goal to 'build a true single market for capital' for all 28 European Union (EU) member states by 2019 (EC 2015). The rationale behind this ambitious project is clear: only a unified and enlarged European capital market can provide extra sources of finance on the scale and on the terms needed to boost investment and pull Europe out of its post-crisis recession. What is less clear is whether the project is feasible, for the EC hopes to achieve in under five years what has not been achieved in over five decades of ongoing European economic integration. The problem is that while the objective may be praiseworthy there is no realistic prospect of achieving it by the means proposed, given that the Green Paper omits any reference to the most formidable of all impediments blocking the creation of a true single European capital market: namely, the German government's stance both on its own debt and on any possible issues of debt at EU level.

Despite the fact that the nominal yield on its bonds has steadily fallen since the financial crisis to the point where it is now hovering around the zero mark, the German government has steadfastly refused to take advantage of this development to increase its expenditures in

Received 3 February 2017, accepted 13 February 2018 
any growth-generating projects. This refusal, enshrined in its 2009 Basic Law on debt brakes, has understandably come under heavy criticism from a wide variety of quarters including the IMF (see, for example, Elekdag/Muir 2014). However, while much attention has been given to the inhibiting effects on real sector growth caused by the German government's tight fiscal stance, considerably less attention has been given to the equally inhibiting effects of this same stance on European capital-market development. This is possibly one explanation of why the EC makes no mention of the German government's fiscal policy in its Green Paper. Another factor may be that the EC does not think it politically judicious to confront the German government on an issue that the latter finds highly sensitive. A further explanation is that the EC broadly agrees with the rationale behind debt brakes as shown in its willingness to coordinate the implementation of debt brakes across the EU as agreed in the Fiscal Compact of 2012 (EC 2012). Whatever the explanation, the inescapable fact is that the German government's reluctance to increase the supply of its bonds is depriving the European capital market of one of the essential ingredients necessary to its enlargement on the one hand and to the efficiency of its operation on the other: the former because capital-market enlargement crucially depends on attracting institutional investors such as pension funds and insurance companies who for various reasons have to hold a substantial proportion of their bond portfolios in the form of safe government bonds; the latter because the efficient functioning of the long-term capital markets crucially depends on the efficiency of the short-term money markets where safe government bonds are by far the most important form of collateral.

The structure of this paper is as follows. Section 2 briefly outlines the importance of high-rated government bonds in the capital and money markets. Section 3 spells out the consequences of Germany's debt-brake policy for the European long-term capital markets. Section 4 spells out the consequences of this policy for the European short-term money markets. Section 5 concludes.

\section{GOVERNMENT BONDS IN THE CAPITAL AND MONEY MARKETS}

The rationale behind the EC's plan to build a genuinely integrated and enlarged European capital-market union by 2019 is sound enough: better-integrated capital markets would, as the EC says, 'enhance the shock absorbing capacity of the European economy' (EC 2015: 4) by making it less heavily reliant on banks and thus less vulnerable to a tightening of bank lending. Elaborating on this rationale, the EC argues that the development of Europe's bond markets is a particularly important priority in that it can help reduce the burden on Europe's commercial banks both in a direct sense, insofar as more businesses can be encouraged to turn to bond issuance for their financing needs, and in an indirect sense, insofar as an increased proportion of bank loans to small businesses and households can be taken off banks' balance sheets and securitised. This argument is absolutely correct but, because this is the case, it is all the more absurd that the EC's Green Paper makes no reference to sovereign bonds, for the reality is that there cannot be any expansion of the European bond markets without a corresponding expansion in the supply of bonds issued by creditworthy European governments. There are basically two reasons for this.

The first is that the large institutions that dominate the buy side of the bond markets, namely commercial banks on the one hand and asset managers such as pension funds and insurance companies on the other, need to hold a substantial proportion of their bond portfolios in the form of government bonds to meet regulatory, prudential and liquidity requirements. While government bonds share in common with corporate bonds the fact that the payment of interest is legally binding in contrast to the payment of dividends on 
equities, which is discretionary, they nevertheless differ from corporate bonds in essential respects: government bonds typically represent the safest form of investable asset because governments have the power of taxation and confiscation; this same power means that government bonds are also the archetypal 'information-insensitive' assets, that is, assets which are immune to adverse selection in trading because agents have no need to acquire private information about the current health of the issuer; finally, the sheer depth of the markets for government bonds means that these typically represent the most liquid type of assets (that is, assets that can be traded in substantial volumes while causing minimal price impact). These distinguishing characteristics of government bonds explain why they are generally used as the benchmarks against which all other bonds are priced, why they are the dominant constituents in the bond market indexes that are widely used by institutional investors for bond portfolio management purposes, and why, as we say, commercial banks and asset managers are required to hold substantial amounts of these bonds in their portfolios.

The second reason for the importance of government bonds to the capital markets is the role they play in the short-term money markets. Large, deep and liquid capital markets can only exist with the aid of various support services, and these services can in turn only be provided on the scale and with the efficiency required if brokers, dealers and other financial institutions are able to borrow and lend cash and securities in whatever volumes and with whatever frequencies are necessary. While a minority of these borrowing and lending transactions (overnight interbank transactions being the most typical) take an unsecured form, the great majority involve the use of collateral in order to minimise counterparty risk. This much is acknowledged by the EC, as it states in its Green Paper: 'Collateral is a vital part of the financial system as it underpins a large number of transactions in the market and provides a safety net in case there are problems' (EC 2015: 23). However, the EC then fails to acknowledge the fact that the superior forms of collateral are safe, information-insensitive and liquid bonds, in other words, the bonds of creditworthy governments.

It can be taken as given that the authors of the EC's Green Paper are well aware of the importance of government bonds in the capital and money markets. It follows that the most plausible explanation for the omission of these considerations is political, namely a reluctance to antagonise the government of what is today the most powerful European economy. While many governments view their outstanding bonds as nothing other than quantities of debt that have to be kept under tight control, none adheres to this viewpoint more religiously than does the German government. In its case certain interpretations of history together with the continuing weight of moral and cultural attitudes to indebtedness have produced a fear of issuing government bonds that is little short of pathological. The German government has always made it a priority to maintain a balanced budget over the economic cycle and when forced by circumstances to issue bonds above a given threshold it tries to get back below that threshold as quickly as possible. Just such a pattern was recently repeated after the financial crisis when the German government, forced to increase the volume of its debt to finance its various crisis-containing measures, almost immediately sought to reduce this volume through the incorporation of a budgetary correction mechanism or 'debt brake' into the German constitution in 2009. ${ }^{1}$

1. Under the provisions of the Basic Law the cyclically adjusted fiscal deficit of the Federal government should not exceed 0.35 per cent of GDP (target date 2016) while the Länder should have cyclically adjusted balanced budgets (target date 2020). For details and a critique of these measures, see Truger/Will (2013). 
Although the German government was not the first European government to incorporate a debt brake into its constitution (Switzerland, for example, had done so earlier) it was the first to do so in the EU, a fact which is of crucial importance because it used Germany's position as the most powerful EU economy to persuade as many as possible of the other EU member-state governments to adopt similar debt brakes. Under the force of this persuasion, 25 out of the $27 \mathrm{EU}$ national governments (those of the UK and the Czech Republic having opted out) signed the Fiscal Compact in March 2012, the major terms of which were that the structural budget deficit should not exceed 0.5 per cent of GDP over the medium term and that this arrangement be anchored in the national constitution or on a comparable national legal basis. It was again German government pressure that led the EC to issue a document in June 2012 in which it agreed to coordinate and monitor the implementation of debt brakes in the countries that had signed up to the Fiscal Compact. Although the German authorities complained that the EC's document had several weaknesses (for example, it did not prescribe mandatory constitutional status for the budgetary correction mechanism) (see, for example, Deutsche Bank 2012), the fact remains that the EC agreed to the proposal for a uniform 0.5 per cent of GDP maximum ceiling on structural budget deficits and in so doing had committed itself to a policy that was in direct contradiction to its subsequent policy aimed at promoting European capital-market development.

In a sense the EC's 2012 stand on European debt brakes and its 2015 plan for European capital-market expansion both appear to represent the same type of supply-side measures intended to boost European economic growth in the wake of the financial crisis: the former because lower government debt burdens are expected to enhance the allocative efficiencies of market mechanisms ${ }^{2}$ and the latter because a reduced cost of capital through the creation of a larger and deeper capital market is expected to encourage more job-creating investments. However, the two initiatives are deeply contradictory, as becomes clear as soon as the bond portfolio and collateral needs of the commercial banks and other large financial institutions are brought into the picture. On the one side, European capital-market enlargement is conditional on increasing amounts of safe government bonds being made available to these institutions, but on the other this condition is blocked by the imposition of debt brakes. The negative effects of this contradiction are serious but nowhere are they more so than in relation to German government bonds as we shall now see.

\section{GERMANY'S DEBT-BRAKE POLICY AND THE EUROPEAN CAPITAL MARKETS}

The project of a capital-market union is emphatically intended to cover all member states and thus attempts to use the relative dynamism of the UK economy and the sophistication of London's financial sector to reinforce the financial integration process. ${ }^{3}$ However, this does not alter the fact that sterling will never be more than a secondary currency in EU finance. All of the large continental European economies are in the eurozone. It thus follows that an enlarged European capital market entails an enlarged eurozone capital

2. Although there is no doubt that very high levels of public debt are an obstacle to economic development, there is no simple relationship between public debt and economic growth and no clear threshold above which public debt becomes a handicap (see Lysandrou 2013). This was also shown by the exposure of multiple empirical errors in the work of Reinhart and Rogoff, who postulated just such a threshold (see Herndon et al. 2014).

3. The Bank of England gave a strong welcome to the Green Paper (Bank of England 2015; Anderson et al. 2015). 
market, which must in turn entail a corresponding supply of euro-denominated government bonds for the reasons specified above. In theory, there are a number of ways in which this condition can be met. The first is for a central eurozone institution to issue bonds that carry essentially the same 'sovereign' characteristics as do US treasuries or UK gilts. The problem is that this is not a feasible option as it runs counter to the very structure of the eurozone. This is because its central bank cannot be relied on to give unlimited support to government bond prices, as is normally the case for national governments strong enough to borrow in their own currencies. On the contrary, the mandate of the European Central Bank (ECB) explicitly excludes such purchases. In the terms used by Aglietta (2014), the eurozone is not defended by a sovereign power while the states within it do not have access to central-bank support and the monetary union is in consequence 'incomplete'.

A second possible solution to the eurozone sovereign bond problem would be for the bonds of the eurozone member states to be regarded in the capital markets as substitutable securities carrying more or less the same safety and liquidity characteristics. Following the establishment of the euro it seemed for a while that this solution could actually work in practice as indicated by the convergence in government bond yields towards that on the German Bund (see Figure 1). The elimination of currency risk, the strong growth performance of the eurozone economies and the ensuing confidence in the stability of the eurozone as a whole all combined to induce investors to ignore the persisting structural and institutional differences between the eurozone countries and hence also the corresponding differences in sovereign credit risk. However, these differences could no longer be ignored once the effects of the 2007-2008 financial crisis started to take their toll on the eurozone economies and on the finances of the eurozone governments. On the contrary, the issue of sovereign credit risk suddenly became the major source of concern for investors as attested to by the sharp divergence in eurozone government yields after 2008. Tober (2016), in a paper whose argument converges with our own, emphasises the advantages of fiscal coordination in the eurozone combined with reciprocal guarantees of all, or a substantial proportion of, the government debt issued by all member states. This would certainly resolve the shortage of safe euro-denominated assets. However, it would conflict with the current policies which actively maintain differentiated risk premia on the bonds of different member states as a way of reinforcing fiscal discipline.

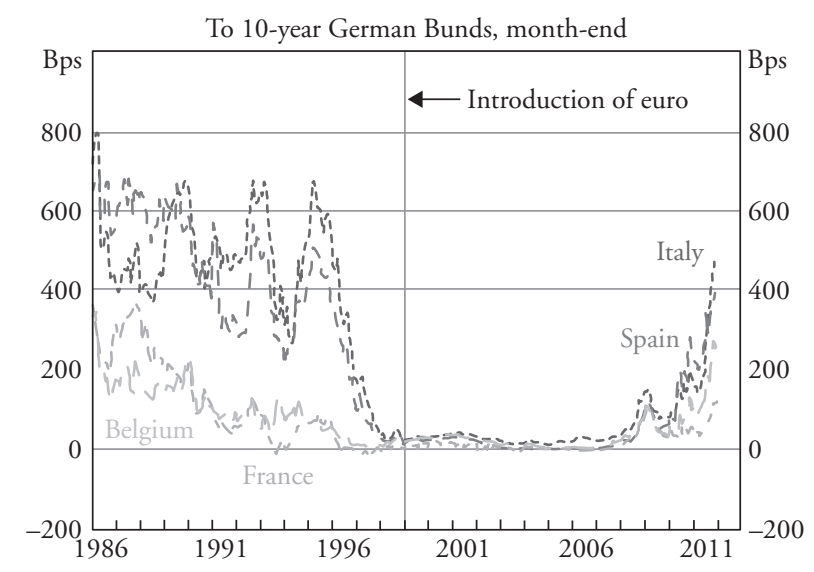

Sources: Bloomberg; Global Financial Data; Thomson Reuters.

\section{Figure 1 European government bond yields}


A third possibility is the creation of a new eurozone sovereign bond. In November 2011, the EC presented a Green Paper in which it argued the economic case for the common issuance of sovereign bonds among the eurozone member states (EC 2011). It believed that in the short term the introduction of joint government guaranteed eurobonds 'could potentially quickly alleviate the current sovereign debt crisis, as the highyield Member States could benefit from the stronger creditworthiness of the low-yield Member States' (ibid.: 2). As for the longer term, the EC believed that a substantial issuance of eurobonds could make the whole eurozone financial system more resilient to future adverse shocks and reinforce financial stability while at the same time strengthening the position of the euro as an international reserve currency, thus fostering a more balanced global financial system. However, a number of the 'low-yield Member States' led by Germany strongly objected to the eurobond proposal. They were simply not prepared to help share the debt burden of governments that, in their opinion, had borrowed excessively and circumvented the eurozone rules over many years.

The final possible solution to the eurozone sovereign bond problem is for the government of the strongest eurozone economy to take upon itself the responsibility of acting as the bond supplier of last resort. This solution is also unworkable, although in this case the impediment has more to do with ideological dogma than any institutional or economic constraint. We are of course talking about the German government. There has never been in recent history any problem about the quality of Bunds, as they were considered risk-free and information-insensitive because the strength of the German economy was such that the state's taxation powers alone were regarded as a sufficient guarantee against default, even in the absence of central-bank support. Neither is there a problem with the quality of Bunds today, as shown by the fact that these alone amongst the larger eurozone government bonds continue to carry a triple-A credit rating. ${ }^{4}$ Rather, the main problem today is with the quantity of Bunds in circulation. It is true that in the wake of the financial crisis that quantity has increased appreciably, with the result that the German government debt to German GDP ratio currently stands at an unusually high level. ${ }^{5}$ In the context of the current discussion, however, this is not the main point. Because German Bunds are the only triple-A-rated eurozone government securities and therefore the only ones that meet all of the safety and liquidity requirements needed by investors, the more relevant size statistic is the quantity of Bunds in relation to the entire eurozone economy rather than just to the domestic German economy and on this criterion that quantity remains comparatively small. ${ }^{6}$

Unfortunately, while euro capital market logic dictates that the German government should continue to increase its supplies of Bunds, the incorporation of a debt-brake law into its constitution in 2009 declares its determination to reduce these supplies. There already exists a convincing critique of the debt brake in terms of its potential impact on aggregate income and expenditure; in the event of a serious recession the implied budgetary policies could become extremely pro-cyclical (Paetz et al. 2016). The present

4. As of June 2015, Germany and Luxembourg alone of the eurozone member states received triple-A rating from the three leading crediting-ratings agencies.

5. At end 2010, central German government debt stood at 53.3 per cent of German GDP (the ratio for general government debt was 83.3 per cent). By 2014 this figure had reached 61.7 per cent, which to the German government may seem high but not when compared to the figure for US Treasuries (96.2 per cent of US GDP in 2014) or to the figure for UK gilts (97.4 per cent of UK GDP in 2014) (IMF international financial statistics, July 2015).

6. In 2011, German government debt liabilities comprised 24.3 per cent of all eurozone government liabilities but by 2014 that ratio had declined to 21.3 per cent (IMF international financial statistics, July 2015). 
argument adds a complementary critique of the debt brake's impact on the financial system. Apart from its fear that unusually high levels of government debt could have detrimental domestic macroeconomic effects, another major motive behind its debt-brake policy is the concern to set an example to other indebted European governments. As argued above, it was the German government that was the principal driving force behind the EU-wide adoption of a Fiscal Compact in 2012, and this government obviously believed that it could hardly insist on the introduction of debt brakes in other countries if had not first introduced this policy at home. The problem with this belief lies not only in the idea that debt brakes should be introduced in all countries regardless of any structural or institutional differences between them but also in the idea that there is a single government debt-to-GDP ratio at which the debt brake should be triggered (the essentially arbitrary limit of 60 per cent which was a rule under the Stability Pact, although never consistently enforced by the EC, was repeated and reinforced in the Fiscal Compact which requires its transposition into member-state legislation). A uniform government debt rule presupposes the idea of debt independence: one must assume that one government's debt threshold has no direct connection to that of any another government if one is to assert that there can be such a thing as a single, one-size-fits-all threshold. However, this assumption of debt independence leaves out of the equation the portfolio needs of institutional investors. Once these are factored into the equation, the respective percentage sizes of government debt thresholds cannot be mutually independent but must, on the contrary, be mutually dependent in which case they can also be unequal. The logic is straightforward: if in any period of prolonged economic slowdown private corporations are unable to produce safe assets with a sufficient storage capacity to accommodate investor wealth, then national governments must make up for this shortfall by increasing their bond supplies; it further follows that if one set of governments are constrained for whatever reason from contributing to bond supplies on the scale required by investors then the latter have no choice but to rely on another set of governments that can supply bonds on the required scale and, of course, the greater the reliance on these governments, the more their debt threshold is pushed above that which is the average for other governments (see Lysandrou 2013 for a more detailed exposition of this argument). Figures 2 and 3 illustrate this alternative idea of debt interdependence.

Figure 2 shows government bond yields and government debt-to-GDP ratios for four eurozone countries over a 20-year period up to 2011. During the latter part of this period government debt-to-GDP ratios rose from an average of 50 per cent to an average of close to 100 per cent. Now, if the idea of debt independence and the concomitant idea of a onesize-fits-all debt threshold were valid, we should have seen all eurozone government bond yields rise uniformly in line with the rise in the debt-to-GDP ratios as investors perceived a threat of default and threatened exit accordingly. As can be seen in Figure 2, this did not happen. While there were positive correlations between yields and debt-to-GDP ratios for certain governments, notably those on the eurozone periphery, for example Greece and Ireland, there was no similar correlation in the case of the governments of core eurozone economies, for example Germany and France: nominal yields on their bonds generally remained flat even while their debt levels rose sharply. The primary reason for this, shown clearly in Figure 3, is that the funds pulled out of the periphery eurozone government bonds by investors were channelled into the relatively safe core eurozone government bonds.

An understanding of this debt interdependence makes it clearer why the composition of the investor base in the core eurozone government bond markets has an important bearing on the proposed enlargement of the European capital market. The crux of the matter concerns the contribution that international investors can make to that project. 
Greece
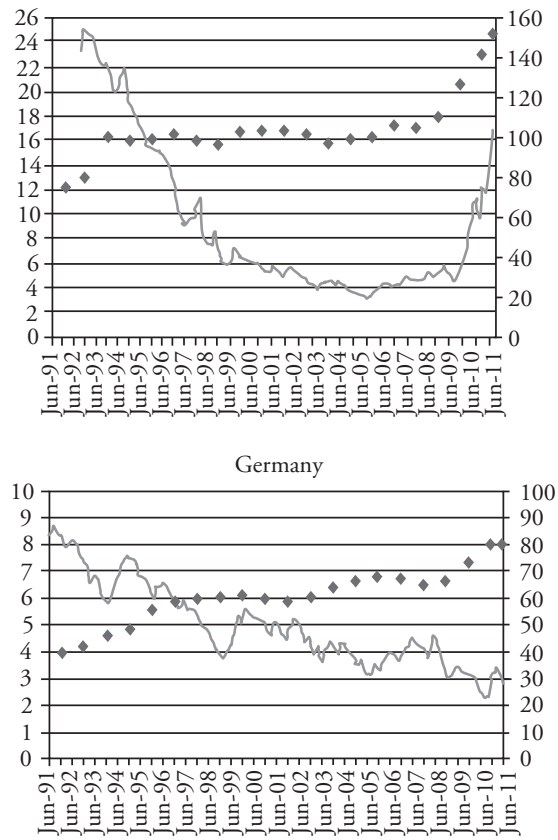

Ireland

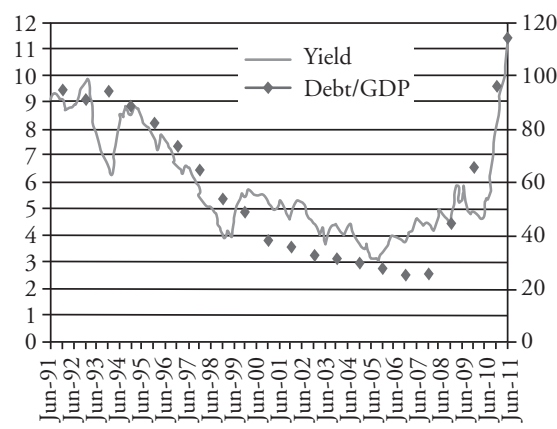

France

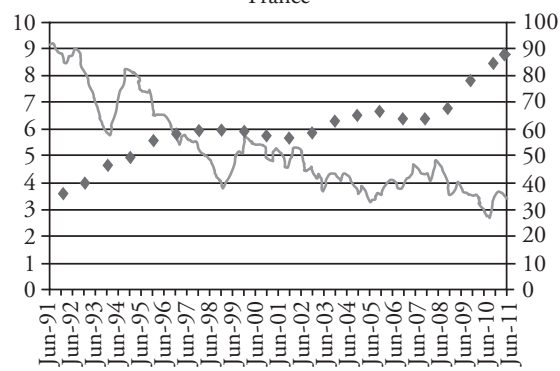

Source: IMF (2011a; 2011b).

Figure 2 Yield and debt-GDP ratios for four eurozone countries

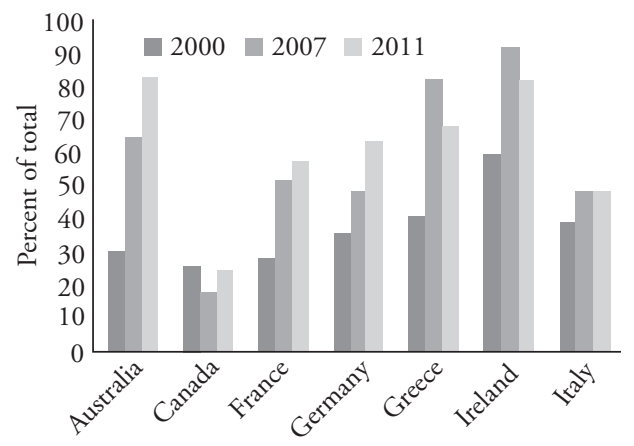

Source: Andritzky (2012).

Figure 3 Non-resident holdings of government securities

The EC itself recognises the potential importance of this contribution for, as its states in its Green Paper, '[ $t$ ] he size of the capital market ultimately depends on the flow of savings into capital market instruments. Thus, for capital markets to thrive, they need to attract institutional, retail and international investors' (EC 2015: 16). As can be seen in Figure 4 (overleaf), the US and UK capital markets do attract a substantial flow of savings from 


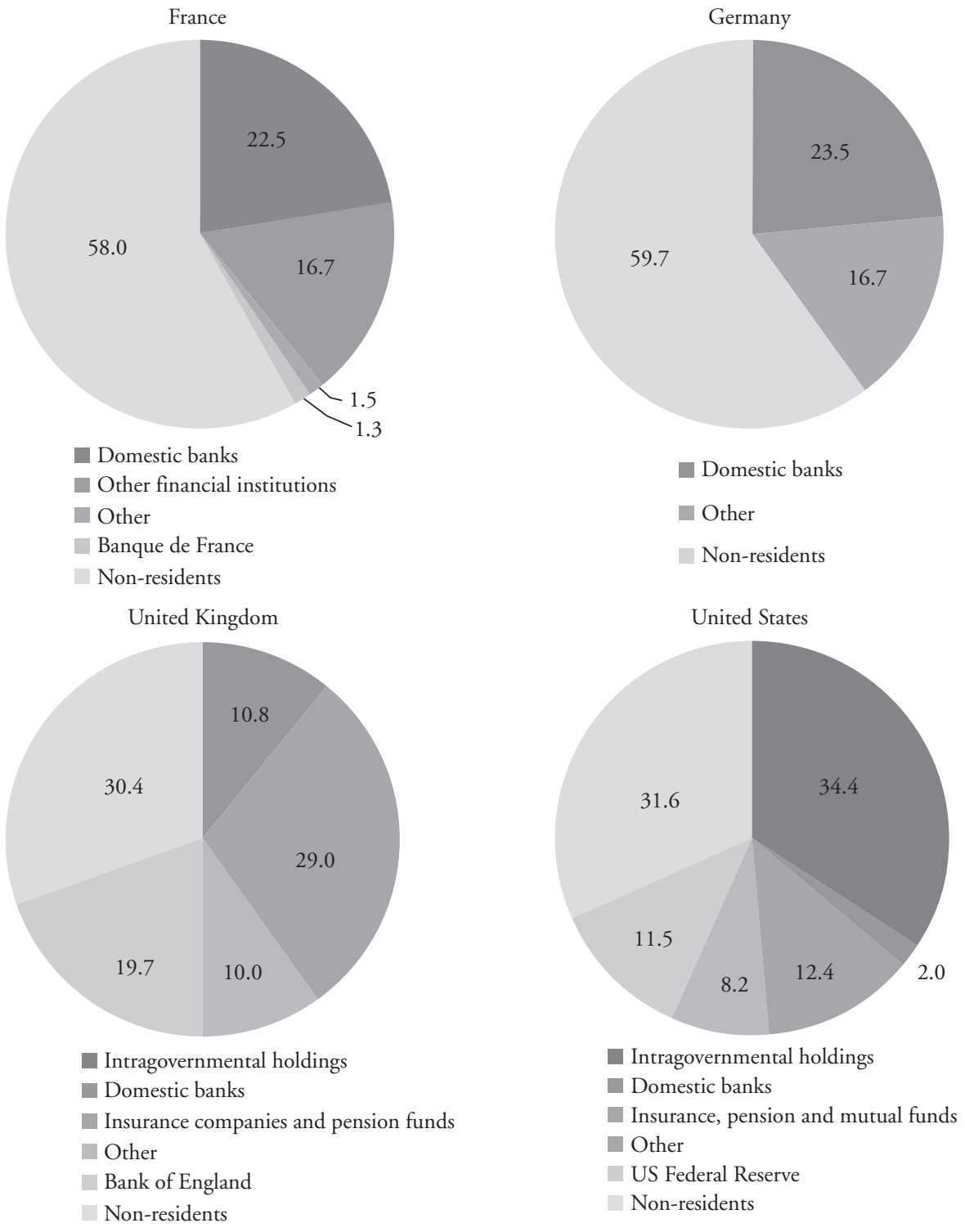

Source: Andritzky (2012).

Figure 4 Main holdings of government debt

international investors in that their non-resident investors are from other currency jurisdictions. In the cases of Germany and France, by contrast, the non-resident investors in their government bond markets are primarily institutional investors based in other eurozone countries. To quote from a recent IMF paper on government bonds and their investors: 'Despite the apparently very high share of non-resident holdings in the euro area, on 
aggregate the euro area depends less on foreign buyers than the United Kingdom or the United States' (Andritzky 2012: 8)

Thus if institutional investors from outside the eurozone are to be attracted in large numbers into the eurozone bond markets there needs to be an increased amount of high-grade eurozone government bonds made available to them which means in practice an increased amount of German Bunds. This entails either that the German government increases its supply of these securities or that the existing German and other eurozone institutional holders of Bunds are encouraged to cut their holdings. Neither solution looks likely as things currently stand. The debt-brake law in Germany means that the German government has voluntarily ceded any latitude over its bond supplies, while the continuing economic difficulties in the eurozone periphery mean that non-resident eurozone institutional investors are hardly likely to leave the safety of German Bunds. This leaves the amounts held by German banks and German insurance companies and pension funds. German banks will not reduce their holdings for regulatory and other reasons, but neither will there be much willingness on the part of the German institutional investors to reduce Bund holdings despite the mounting difficulties caused by the drop in Bund yields.

These difficulties are widespread in that the dearth of high-quality government bonds in the eurozone and in the wider EU are affecting institutional investors who need to provide a stable return for their retail customers but who face the dilemma of either accepting negative returns on the best securities or purchasing inferior assets which expose their customers to inappropriate levels of risk. ${ }^{7}$ However, the most severe example of these problems is given by the German insurance sector. Insurance, including long-term savings schemes linked to life assurance, is particularly important in continental Europe as indicated by the fact that the assets held by EU insurance companies exceed those of their US counterparts, the only financial sector for which this is the case. In 2014, two Bundesbank economists, Kablau and Weiss, published a paper in which they assessed the financial strength of German insurance companies. They found that in the baseline scenario, where bond yields move back towards more normal levels as they are officially predicted to do, all is well provided that the companies refrain from paying dividends to shareholders. But they went on to argue that, should interest rates continue to remain low, large numbers of German insurance companies would be forced into default. In a 'mild' stress scenario, modelled on recent Japanese experience, 12 of the 85 life insurance companies analysed would violate the capital requirements specified in EU directives by 2023. In a stricter stress test, where it is much harder to acquire earning assets, 32 enterprises, more than a third, would default by $2023 .{ }^{8}$

7. John Dizard (2015), a leading commentator on fund management for the Financial Times wrote recently that 'the policy regime [in the eurozone] has now made it mathematically impossible for fiduciaries to meet the beneficiaries' future needs through the prudent buying of securities'. In an earlier critique from within Germany, Truger/Will (2013: 5), similarly point to serious difficulties for the capital markets in general and private-sector pension provision in particular: 'It must be feared that the capital markets, through the Schuldenbremse and by the attempt to narrow the volume of the long-standing safest form of placement will lose an important stability anchor and an important guideline. It is unclear to which countries in the future the traditionally high savings surplus of the German private sector, and, among others, the private provision for pensions, will flow; in the long run the financial markets may become significantly more unstable'.

8. Our citation of this study does not imply more general support for Bundesbank positions. These certainly criticise the extremely accommodating stance of the ECB and refer to the negative impact on savers but make no objection to the severe fiscal stance of the EU governments which in reality makes that monetary policy necessary. 


\section{GERMANY'S DEBT-BRAKE POLICY AND THE EUROPEAN MONEY MARKET}

Germany's introduction of a debt-brake law into its constitution in 2009 has had as severe an inhibiting effect on the short-term money markets of the eurozone as on its long-term capital markets. To see this, consider the nature and functions of the most important of all money market instruments, the repo. The repo is a type of securitised financing transaction: one party sells an asset to a counterparty at a given price and commits to repurchase the asset at the same price, plus an interest-rate component, at a specified future date. If the borrower of cash (the repo seller) defaults during the life of the repo, the cash lender (the repo buyer) can sell the asset to a third party to offset the loss; in other words, the asset acts as collateral and thus reduces the credit risk for the lender.

In a recent publication on repos, ICMA (2015) argues that this instrument is pivotal to the efficient functioning not only of the money markets but also of the entire financial system because of the wide range of its uses, the most notable of which are:

1. to provide an efficient source of money market funding: 'by offering deposits secured against high quality assets, by diversifying the credit exposure of cash investors beyond the banking sector and by disintermediating traditional but less competitive financial channels, the repo market mobilises cheaper and deeper funding for financial intermediaries, which in turn lowers the cost of financial services to investors and issuers';

2. to provide a secure home for liquid investment: 'the capacity of repo, collateralised by liquid high quality securities, to mitigate risk is particularly valued by risk averse end-investors seeking a secure, liquid investment for temporary cash balances and working capital';

3. to broaden and stabilise the money market: 'the collateralised nature of repo allows a wider array of borrowers and lenders into the wholesale money market than just commercial banks. The resulting breadth and diversification creates a deeper and more robust market, which facilitates liquidity management between financial intermediaries and reduces systemic risk';

4. to hedge primary debt issuance: 'in the primary debt market, repo allows dealers to fund their bids at bond auctions and underwriting positions in syndicated bond issues at reasonable costs, thereby providing cheaper and less risky access to the capital markets for issuers';

5. to ensure liquidity in the secondary debt market: 'liquidity in the secondary market for securities depends upon primary dealers and other market makers being willing to quote selling and buying prices continuously to investors', a willingness that in turn depends on the ability to use repos 'to fill in any temporary gaps in inventory holdings or to hedge the risk on temporary accumulations of holdings'.

Excessively liquid repo markets were admittedly one factor leading up to the global financial crisis (FSB 2012; Gabor 2012). However there is no doubt that these markets are absolutely central to the functioning of both bank-based and security-market-based finance. The EC's capital-market Green Paper certainly recognises the importance of the repo as shown in the quotation above and which is worth repeating here: 'Collateral is a vital part of the financial system as it underpins a large number of transactions in the market and provides a safety net in case there are problems'. Also worth repeating is the curious fact that while the EC notes that the repo is a relatively safe credit transaction precisely because it relies on the use of collateral, it does not specify the types of assets that are best suited to serve as collateral. 
In reality, it is only highly rated government bonds that unambiguously fulfil this condition. To draw again on ICMA's statement on repos: 'Ideally, collateral should be free of credit and liquidity risk. The market value of such perfect collateral would be certain and it would be easy to sell in the event of the default by the collateral-giver. The type of asset that comes closest to this paradigm, and is in fact the most commonly used type of collateral in the repo market, is a bond issued by a creditworthy central government'. ICMA recognises that there are other less highly rated assets that can be used as collateral in repos, which are called 'credit repos' and which include bonds issued by emerging-market governments, large corporations and banks, but by far the predominant type of collateral is the triple-Arated government security. In its most recent semi-annual survey of the European repo market, ICMA (2014) estimates that this collateral class accounts for almost 80 per cent of EU-originated repo collateral. When other, less recognisable and more risky assets are deployed, there might no longer be an absolute shortage of collateral, but shortage now takes the form of a corresponding problem of misallocation as the ability to assess the assets concerned is a specialised capacity, possessed fully by only some of the potential lenders in a repo operation (Anderson/Joeveer 2014).

The upshot of the above discussion is that the financial crisis has thrown up serious barriers to the EC's plan for an enlarged European capital market even as the persistent economic slowdown resulting from the crisis has made it all the more urgent that the EC executes such a plan. Collateral shortage is central to this conundrum. The reason why the financial crisis has caused the shortage to become a particularly acute problem is that it has on the one side served to boost the demand for good-quality collateral while it has at the same time served to undermine the supply of such collateral. The demand side of the problem boils down to the near-total collapse of trust between the large commercial banks. As can be seen in Figure 5, prior to the financial crisis in 2007-2008 unsecured interbank borrowing and lending transactions comprised a significant proportion of money market activity, but since the crisis such transactions have fallen sharply as more of the major lenders of funds have sought to protect their loans with collateral. The supply

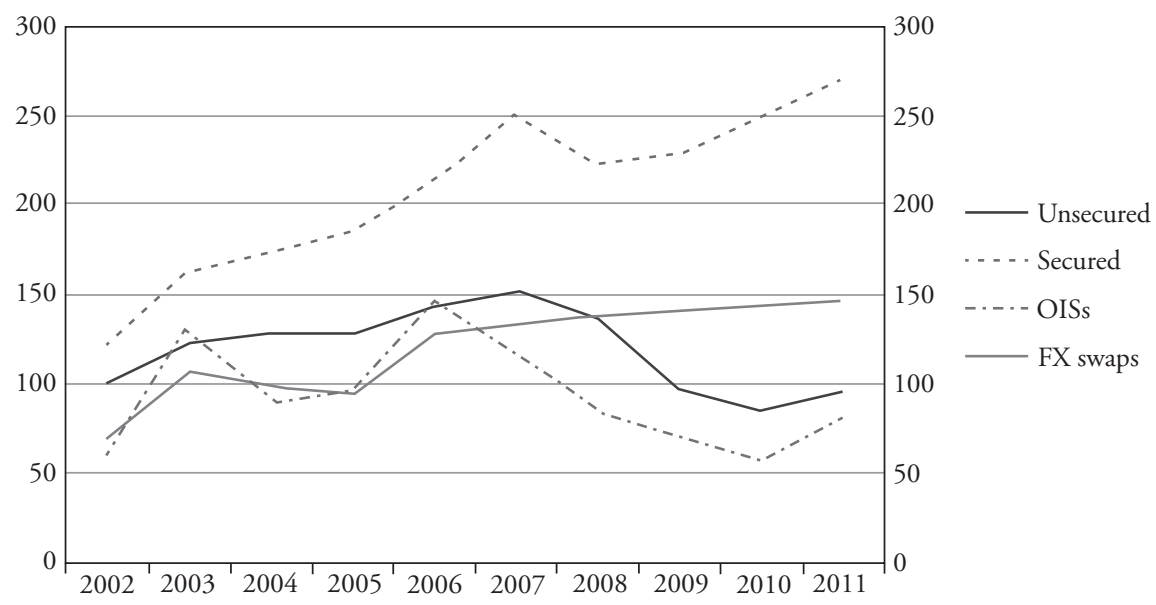

Source: ECB (2011).

Figure 5 Average daily turnover in various money market segments (index: unsecured transaction volume in $2002=100$ ) 
side of the collateral shortage problem comes down to the renewed divergence in the credit ratings on the bonds issued by eurozone governments. While most of these governments received high ratings in the pre-crisis period of strong eurozone growth, because the elimination of currency risk contributed to the convergence of these ratings and the accompanying convergence in bond yields, the ratings again began to diverge significantly following the crisis as a consequence of the differential impact on the public finances of the eurozone member countries.

Although the EC's capital-market Green Paper draws attention to the collateral shortage problem, what is interesting is that it does so in a partial, unbalanced way: 'The fluidity of collateral throughout the EU is currently restricted, preventing markets from operating efficiently. Since the financial crisis, the demand for collateral has increased, driven by market demand for more secured funding as well as new regulatory requirements, such as set out in the European market Infrastructure Regulation (EMIR) and Capital markets Regulation (CRR)' (EC 2015: 23). While reference is here made to the post-crisis increase in the demand for collateral, there is no reference at all to the decrease in the supply of collateral caused by the crisis. Given that the authors of the Green Paper can hardly have been unaware of the supply-side dimension of the collateral shortage problem, particularly as this dimension has been well documented in several authoritative publications, ${ }^{9}$ one can again only surmise that the reason for this omission is a reluctance to draw attention to the German government's debt policy. Yet the fact remains that it is precisely this policy that is a major cause of collateral shortage at the present time. ${ }^{10}$ Since the German government is the only major continental European government that continues to have a triple-A rating, this government should continue to increase its supply of these bonds at a rate commensurate with the increase in the investor demand for them if the problem of collateral shortage is to be avoided or, at the very least, contained. That this is not happening is clear from Table 1. Rather than continually rising in the period since the financial crisis, the percentage share of Bunds in eurozone-generated collateral has continuously fallen as their supply has failed to keep pace with the competing demands for them, stemming from both the capital markets and the money markets.

There are two major negative effects of collateral shortage, only one of which is acknowledged in the EC's Green Paper. This is the 're-hypothecation' of collateral, which, as formally defined by ICMA (2015: 10), is a practice whereby 'a party who receives a pledge of collateral pledges the same collateral to a third party'. While the economisation of collateral represents a possible upside of the re-hypothecation process, its downside is the complexity of the operational procedures that are required for the efficient management of re-hypothecated assets. The greater is the re-hypothecation chain, the greater are the complexities of the operational procedures and the greater therefore are

9. Levels/Capel (2012), for example, give evidence that collateral is becoming scarce in the euro area. Andrew Hauser (2013), Head of the Bank of England's sterling market division, has warned of the problems that can arise when there is a shortage of quality collateral at the very time that the post-crisis concern with stability in the repo market actually increases the importance of such collateral. As he argues, the repo market, at least in some respects, tends to function in a pro-cyclical way: the haircuts or discounts applied to collateral assets widen in times of stress while the range of acceptable assets narrows. German policy through the economic downturn powerfully reinforces these pro-cyclical effects.

10. The Green Paper, however, implicitly recognises the need for high-quality government-issued bonds in its call for bond-financed infrastructure projects where, presumably, either EU institutions or some combination of member states would sponsor the underlying investment and guarantee service of the debts incurred. The Bank of England (2015) makes the same call. However, this attempt to finesse the Schuldenbremse seems highly likely to fail in the face of German opposition to EU-level borrowing. 
Table 1 Collateral analysis for the eurozone

\begin{tabular}{lccc}
\hline & June 2013 & December 2013 & June 2014 \\
\hline Germany & $21.9 \%$ & $21.9 \%$ & $19.1 \%$ \\
Italy & $8.2 \%$ & $9.2 \%$ & $10.6 \%$ \\
France & $11.7 \%$ & $11.5 \%$ & $10.9 \%$ \\
Belgium & $3.4 \%$ & $3.0 \%$ & $2.9 \%$ \\
Spain & $4.6 \%$ & $5.2 \%$ & $6.3 \%$ \\
Other eurozone & $8.1 \%$ & $7.2 \%$ & $7.3 \%$ \\
UK & $12.0 \%$ & $11.4 \%$ & $10.6 \%$ \\
DKK, SEK & $2.9 \%$ & $2.8 \%$ & $2.8 \%$ \\
International financial institutions & $2.2 \%$ & $2.7 \%$ & $2.4 \%$ \\
US & $2.6 \%$ & $2.8 \%$ & $2.6 \%$ \\
Accession countries & $0.3 \%$ & $0.4 \%$ & $0.4 \%$ \\
Japan & $4.2 \%$ & $4.6 \%$ & $4.8 \%$ \\
Other OECD & $12.1 \%$ & $10.3 \%$ & $11.2 \%$ \\
Other fixed income & $5.6 \%$ & $6.6 \%$ & $8.0 \%$ \\
Equity & $0.3 \%$ & $0.3 \%$ & $0.1 \%$ \\
\hline
\end{tabular}

Source: ICMA (2014).

the risks of their possible breakdown. The $\mathrm{EC}$ recognises this point, for as it states in its Green Paper, ' $[w]$ ith demand for collateral rising, there are risks that the same securities are being re-used to support multiple transactions as was the case pre crisis' (EC 2015: 23). However, what the EC does not appear to recognise is the fact that re-hypothecation usually occurs not because of a shortage of collateral in general so much as of a shortage of high-quality collateral in particular: this is because the efficiency of re-hypothecation depends on the market for the collateral asset being as deep and liquid as possible and this condition is only fully met by the market for high-rated government bonds. Were the EC to take this fact into consideration it would have to conclude that the best way of avoiding the risks of excessive re-hypothecation is to ensure that the European money markets are continually supplied with adequate amounts of good-quality government bonds and what this means in practice, given the current realities, is an adequate supply of German government bonds.

A second major consequence of a collateral shortage, not referenced by the EC, concerns the negative impact on the conduct of monetary policy. In addition to the private-sector functions of the repo listed above, the repo market greatly facilitates central-bank operations in the modern era. To again quote ICMA (2015: 5): 'The repo market provides a ready-made collateral management framework without which central banks would not be able to implement monetary policy so efficiently under normal market conditions and act as lenders of last resort so swiftly in periods of market turbulence. Central bank repo feeds seamlessly into the commercial repo market'. Now a key condition for central-bank repo to feed 'seamlessly' into the commercial repo market is that the assets used as collateral in both the public and private segments of the repo markets are denominated in the same currency. This condition is more or less met in the US, where, in addition to Treasury securities, virtually the rest of the US repo market relies on the use of government-guaranteed Agency debt and Agency mortgage-backed securities (MBSs). By contrast, this condition is not met in the eurozone repo market where US dollars figure prominently as one of the assets used as collateral.

We are here talking of the foreign-exchange (FX) swap, a currency instrument that now accounts for nearly one half of the near $\$ 6$ trillion daily turnover on the global 
FX markets. An FX swap is a closed transaction between two counterparties that combines a spot transaction, for example the sale of dollars for euros with an outright forward transaction in the reverse direction, that is, the sale of the euros for dollars. Although FX swaps are generally used for currency-related reasons (for example, the borrowing or lending of a foreign currency) or exchange-rate-related reasons (for example, rolling over a hedged or speculative position on exchange-rate fluctuations), a substantial proportion are used as a repo-type instrument with the difference that it is a key currency rather than a government bond that acts as the collateral. ${ }^{11}$ Although FX swaps are used in this purely money market function in every major currency jurisdiction, this use is most pronounced in the eurozone. An indication of the extent to which eurozone commercial banks rely on FX swaps less for currency-related transactions than for repo-type borrowings is the unusually high ratio of inter-dealer (essentially interbank) FX transactions in the eurozone: 64 per cent (67 per cent for FX swaps) as compared with a rest-of-the-world average of 39 per cent (ECB 2010: 1). This reliance on dollar-denominated collateral is a further, relatively neglected, aspect of the increasing dependence of European financial corporations on the US capital markets, a trend which would eventually make the construction of a European capital market at worst impossible, at best irrelevant. ${ }^{12}$

In general, weakness in the repo market threatens directly to impair the contribution to recovery and growth from the proposed capital markets union. The taking of collateral, by banks and other financial corporations, is essentially a risk-management device. If use of this device becomes more difficult or more costly, it is likely that financial institutions will respond by reducing the risks of their activities. But if they draw in their horns in this way, the stimulus to investment and growth which the EC hopes to achieve from capitalmarket integration will be blunted or nullified (Anderson/Joeveer 2014).

From all that has been said here about the importance of collateral it follows that the EC poses the wrong question when it asks in its Green Paper 'whether work should be undertaken to facilitate an appropriately regulated flow of collateral through the EU' (EC 2015: 23). Such work must of course be undertaken if the EC's plan for an enlarged European capital-market union is to succeed. Rather, the more pertinent question is what work should be done to facilitate the flow of collateral in the EU. By now it should be obvious that the first place to begin this work is in Germany, with the first priority being to convince the German government either to reverse its debt-brake policy or to accept the fundamental change that could establish a European-level institution as a major issuer of high-quality debt securities.

Dramatic evidence of serious malfunctions in eurozone money markets is provided by the astonishing disruption of euro-denominated repo markets at the end of December 2016. Such was the shortage of good collateral that interest rates on repo loans went to -6 per cent (completely losing touch with the very slightly negative rates paid on deposits by the ECB). There were clearly specific factors to do with regulatory and accounting rules which helped to provoke this disruption. But the failure of repo rates to return to normal indicates that there is a continuing 'shortage of readily available high quality liquid assets' (Hill 2017: 10). The same ICMA analysis points out that quantitative easing $(\mathrm{QE})$ by the ECB has exacerbated this shortage - one aspect of $\mathrm{QE}$ as practised by the $\mathrm{ECB}$ is that bonds have to be purchased in proportion to the economic weight of the member-state economies, so that the underlying shortage of German collateral in particular is aggravated.

11. For more detailed discussion of this point, see Grahl/Lysandrou (2003).

12. Grahl/Lysandrou (2014) have stressed this same point in the context of the EC's proposal for a European Financial Transactions Tax. 
Caballero et al. (2017: 34) characterise the general consequences of an inadequate supply of safe assets as 'a modern version of the paradox of thrift: faced with elevated safe real rates (relative to their equilibrium level), households prefer to save and postpone consumption; simultaneously, faced with low demand and elevated risk premia, firms prefer to postpone investment. Aggregate demand suffers and a recession ensues'. In addition, they point to impacts on international economic relations which seem to correspond closely to experience in the eurozone. There is firstly a flow of capital to economies issuing safe assets - in particular the US. This effect is confirmed by the increasing attractiveness of dollar as against euro credit markets for borrowers around the world, as recognised in the ECB's latest report (2017) on the international use of the euro. Secondly there are tensions within the eurozone since all the benefits of bond issuance by the German government cannot be internalised within Germany itself but act as a public good for the monetary union as a whole.

\section{CONCLUSION $^{13}$}

The EC is correct in thinking that the creation of an enlarged European capital market by 2019 depends on overcoming the various obstacles that have thus far kept European capital markets fragmented and underdeveloped. But it is incorrect in its assumption that the only substantive obstacles in question are those to do with regulatory and legal barriers and institutional shortcomings. This is not the case. Even if the EC's action plan for capitalmarket union succeeded in eliminating all of these particular obstacles, effective integration might not result. A necessary condition is that the $\mathrm{EC}$ also confronts a formidable political obstacle, which is the German government's stance on debt. Unless and until that stance is changed, the European government bond markets will remain comparatively undeveloped, as will, therefore, the whole European private capital-market sector. The EC's project expresses its increasing anxiety about economic recovery in the context of general, severe and continuing fiscal consolidation. The critique of that consolidation drive, linked to the introduction of debt brakes, is well known. However, a parallel critique can be made of the consequences of the same debt brakes in the financial sphere and this strongly suggests that no escape from the economic slowdown is at present to be found in more dynamic capital markets since these are impaired by the same restrictive policies. ${ }^{14}$

13. This paper was completed before the result of the British referendum on EU membership was known. However, the decision to leave the EU, if it is in fact implemented, can only further undermine the project for a capital-markets union. That project represents a certain shift of policy emphasis away from the eurozone, mired in stagnation, towards the single market and the UK, perceived as offering a more dynamic prospect. With Britain outside the EU, struggling to overcome the shock of departure, the notion of capital-market growth as compensating for eurozone weakness becomes doubly optimistic. The resignation of Jonathan Hill, the UK Commissioner entrusted with financial reform, in the wake of the referendum, both signals and intensifies this disappointment.

14. Further evidence of the illiquidity of the market in German government debt (Bunds) is offered by market commentators who point out that shortage of government bonds has tended to displace hedging and other activities to the Bund futures market; operations that would be carried out in the US using treasuries are in Europe transferred to the derivatives of the Bund which, being privately issued, are not subject to the same constraints on the volume issued. However, a bond futures market, although a valuable supplement to the bond market itself, cannot be a full substitute for the latter, for example in the supply of collateral assets. 


\section{REFERENCES}

Aglietta, M. (2014): Europe: sortir de la crise et inventer l'avenir, Paris: Michalon.

Anderson, N., Brooke, M., Hume, M., Kürtösiová, M. (2015): A European capital markets union: implications for growth and stability, Bank of England Financial Stability Paper, no 33, February.

Anderson, R.W., Joeveer, K. (2014): The economics of collateral, LSE Systemic Risk Centre, URL: http://ssrn.com/abstract=2427231.

Andritzky, J.R. (2012): Government bonds and their investors: what are the facts and do they matter?, IMF Working Paper WP/12/158.

Bank of England (2015): The Bank of England's response to the European Commission's Green Paper: Building a Capital Markets Union, May.

Caballero, R.J., Farhi, E., Gourinchas, P.-O. (2017): The safe assets shortage conundrum, in: Journal of Economic Perspectives, 31(3), 29-46.

Deutsche Bank (2012): Debt brakes for Euroland, Progress Report.

Dizard, J. (2015): Embrace the contradictions of QE and sell all the good stuff, in: Financial Times, fund management section, 16 March.

Elekdag, S., Muir, D. (2014): Das Public Kapital: how much would higher German public investment help Germany and the euro area? IMF Working Paper WP/14/227.

EC (European Commission) (2011): Green Paper on the feasibility of introducing stability bonds, COM (2011) 818 final, Brussels, 23 November.

EC (European Commission) (2012): Common principles on national fiscal correction mechanisms, COM.

EC (European Commission) (2015): Green Paper: building a capital markets union, COM (2015) 63 final, Brussels, 18 February.

ECB (European Central Bank) (2010): BIS Triennial Survey, 2010: Euro Area Data, Frankfurt: ECB.

ECB (European Central Bank) (2011): Euro money market survey, September.

ECB (European Central Bank) (2017): The international role of the euro, July.

FSB (Financial Stability Board) (2012): Securities lending and repos: market overview and financial stability issues - interim report of the FSB workstream on securities lending and repos, Financial Stability Board, 27 April.

Gabor, D. (2012): The power of collateral: the ECB and geographies of bank funding, Social Science Research Network.

Grahl, J., Lysandrou, P. (2003): Sand in the wheels or spanner in the works: the Tobin tax and global finance, in: Cambridge Journal of Economics, 27(4), 597-621.

Grahl, J., Lysandrou, P. (2014): The European Commission's proposal for a financial transactions tax: a radical critique, in: Journal of Common Market Studies, 52(2), 234-249.

Hauser, A. (2013): The future of repo: too much or too little?, Speech at the ICMA Conference on the Future of the Repo Market, London, URL: www.bankofengland.co.uk/publications/Pages/ speeches/default.aspx.

Herndon, T., Ash, M., Pollin, R. (2014): Does high public debt consistently stifle economic growth? A critique of Reinhart and Rogoff, in: Cambridge Journal of Economics, 38(2), 257-279.

Hill, A. (2017): Closed for business: a post-mortem of the European repo market break-down over the 2016 year-end, ICMA, February.

ICMA (International Capital Markets Association) (2014): European repo market survey, September.

ICMA (International Capital Markets Association) (2015): Frequently asked questions about the repo, May.

IMF (International Monetary Fund) (2011a): International financial statistics database, accessed via the Economic and Social Data Service.

IMF (International Monetary Fund) (2011b): World economic outlook database, accessed via the Economic and Social Data Service.

Kablau, A., Weiss, M. (2014): How is the low-interest-rate environment affecting the solvency of German life insurers?, Deutsche Bundesbank discussion paper, no 27/204. 
Levels, A., Capel, J. (2012): Is collateral becoming scarce? Evidence for the euro area, in: Journal of Financial Market Infrastructures, 1(1), 29-53.

Lysandrou, P. (2013): Debt intolerance and the 90 per cent debt threshold: two impossibility theorems, in: Economy and Society, 42(4), 521-542.

Paetz, C., Rietzler, K., Truger, A. (2016): The Federal government debt brake since 2011: the real test is yet to come, IMK Report 117e, Düsseldorf, IMK at Hans-Böckler-Foundation.

Tober, S. (2016): The ECB's monetary policy: stability without 'safe' assets?, IMK Report 1123, March.

Truger, A., Will, H. (2013): The German 'debt brake': a shining example for European fiscal policy?, in: Revue de l'OFCE, Debates and Policies: The Euro Area In Crisis, 127, 155-188. 